\title{
Model Calculations to Quantify Clinical and Economic Effects of Pathogen Inactivation in Platelet Concentrates
}

\author{
Karin Berger $^{a *}$ Matthaeus Bauer ${ }^{\mathrm{b} *}$ Dorothee Schopohl ${ }^{\mathrm{a}}$ \\ Reinhard Henschler ${ }^{\mathrm{a}}$ Helmut Ostermann $^{c}$ \\ ${ }^{a}$ Department of Transfusion Medicine, Cell Therapeutics and Haemostaseology, \\ ${ }^{b}$ Department of Medical Management, \\ 'Department of Haematology/Oncology, University Hospital of Munich, Munich, Germany
}

\section{Keywords}

Acute transfusion reaction · Cost · Haematology/oncology patients - Pathogen inactivation - Pathogen reduction .

Platelet transfusion

\section{Summary}

Background: Future shortages in platelet supply are expected in Germany due to demographic changes. A rising cancer incidence will lead to an increasing demand for platelet concentrates (PCs) while the number of potential donors will decrease. Pathogen inactivation (PI) aims to inactivate various infectious agents including emerging pathogens to extend the shelf-life of PCs and reduce the frequency of acute transfusion reactions (ATRs). In this context, the clinical and economic impact of PI on platelet transfusion was evaluated. Material and Methods: Model calculations were conducted for 2 scenarios considering different production settings. Frequencies of ATRs were based on literature analyses, platelet and ATR costs on cost analyses. Results: The estimated average costs for ATRs of grade 1 and 2, irrespective of origin, and grade 3 (allergic) were $€ 104$, $€ 238$, and $€ 1,200$, respectively. Approximately 400 PC-related ATRs per $10^{5}$ transfusions can be avoided, with estimated savings amounting to $€ 77,000$. The total cost increase was calculated to approximately $€ 30-50$ per PI-treated PC. Conclusion: PI potentially saves plasma, prolongs shelf-life, decreases donor deferral, and reduces ATRs. Model calculations considering clinical and safety benefits of PI show a rational cost increase. The impact of PI should be further evaluated from a societal perspective regarding future blood supply and infectious disease globalization.

*These authors contributed equally to this study.

\author{
Schlüsselwörter \\ Akute Transfusionsreaktion · Kosten · Hämatologisch/ \\ onkologische Patienten · Pathogeninaktivierung . \\ Pathogenreduktion - Thrombozytentransfusion
}

\section{Zusammenfassung}

Hintergrund: Langfristig werden Engpässe in der Versorgung mit Thrombozyten in Deutschland auf Grund demographischer Veränderungen antizipiert. Der Anstieg der Krebsinzidenz wird zu einem steigenden Bedarf an Thrombozytenkonzentraten (TKs) führen, aber potentielle Spender werden abnehmen. Pathogeninaktivierung (PI) zielt darauf $a b$, eine Vielzahl infektiöser Agentien einschließlich neu auftretender Pathogene zu inaktivieren, die Haltbarkeitsdauer von TKs zu verlängern und die Häufigkeit akuter Transfusionsreaktionen (ATRs) zu reduzieren. In diesem Zusammenhang wurden klinische und ökonomische Auswirkungen der PI auf Thrombozytentransfusionen untersucht. Methoden: Modellberechnungen wurden für 2 Szenarien unter Berücksichtigung verschiedener Produktionssituationen durchgeführt. Häufigkeiten von ATRs basierten auf Literaturanalysen, Thrombozyten- und ATR-Kosten auf Istkostenanalysen. Ergebnisse: Die geschätzten Durchschnittskosten für ATRs Grad 1 und 2, unabhängig von der Ursache, und Grad 3 (allergisch) betrugen 104, 238 und $1200 €$. Ungefähr 400 TKbezogene ATRs pro $10^{5}$ Transfusionen können vermieden werden; geschätzte Einsparungen betragen $77000 €$. Ein Gesamtkostenanstieg von zirka 30-50 € pro PI-behandeltem TK wurde errechnet. Schlussfolgerungen: Potentiell spart PI Plasma, verlängert die Haltbarkeitsdauer, verringert den Ausschluss von Spendern und vermindert ATRs. Modellberechnungen, die den klinischen und sicherheitsrelevanten Nutzen der PI berücksichtigen, zeigen einen rationalen Kostenanstieg. Die Bedeutung der PI sollte aus einer gesellschaftlichen Perspektive unter Berücksichtigung der zukünftigen Versorgung mit Blut und der Globalisierung infektiöser Erkrankungen weiter untersucht werden.

\begin{tabular}{ll}
\hline KARGER & $\begin{array}{l}\text { ( ) 2013 S. Karger GmbH, Freiburg } \\
0378-584 X / 13 / 0361-0053 \$ 38.00 / 0\end{array}$ \\
$\begin{array}{l}\text { Fax +49 761 452 07 14 } \\
\text { Information@Karger.com } \\
\text { www.karger.com }\end{array}$ & $\begin{array}{l}\text { Accessible online at: } \\
\text { www.karger.com/onk }\end{array}$
\end{tabular}




\section{Introduction}

Platelet transfusions are essential to prevent and treat bleeding in thrombocytopenic, immunosuppressed patients with cancer, haematological malignancies, bone marrow failure, and after haematopoietic stem cell or bone marrow transplantation. The risk of bleeding depends not only on the platelet count, but also on the underlying disease, recent haemorrhage, pre-medication potentially influencing platelet function, complications such as sepsis, uraemia, anaemia, necrosis in tumour tissue, and defects in coagulation function $[1,2]$. The usual platelet doses have been in the range of 3-6 $610^{11}$ [3]. A recent large randomized trial in haemato-oncological patients (PLADO trial, Prophylactic Platelet Dose on Transfusion Outcomes) has shown that variations in platelet doses between $1.1 \times 10^{11}$ and $4.4 \times 10^{11}$ platelets $/ \mathrm{m}^{2}$ given in prophylactic platelet transfusions are equivalent in the prevention of bleeding [3]. Factors which can improve platelet responses are the use of ABO-compatible platelets, fresh platelets (stored for $48 \mathrm{~h}$ or less), and administration of large doses of platelets [4]. Platelets in the normal circulation have a mean life span of 7-10 days only [5, 6]. The fact that storing platelets causes well described changes in morphology and biochemistry known as platelet storage lesions explains why fresh platelets are more effective $[6,7]$. Further, platelet products for transfusion are stored at room temperature in plasma or plasma with additive solution under constant agitation, which can promote bacterial growth $[2,6]$.

\section{Risks of Platelet Transfusion}

The known clinical risks of platelet transfusions include infectious complications, immunologic events, and bacterial contamination $[2,6,8]$. Despite thorough donor screening and extensive laboratory testing, the risk of the 'window period of infection' remains. Emerging pathogens, which might be transmitted by platelets, are an additional risk and can lead to considerable shortages in blood supply. Present examples for pathogens transmissible by blood transfusions requiring additional safety measures are the West Nile virus (WNV), severe acute respiratory syndrome (SARS) virus, Dengue virus, Chikungunya virus, and the parasites Trypanosoma cruzi (Chagas disease), Plasmodium falciparum (malaria) and

Table 1. Haemovigilance data regarding platelet transfusions

\begin{tabular}{|c|c|c|c|}
\hline & France [41] & Germany [18] & United Kingdom [42] \\
\hline \multicolumn{4}{|l|}{ Platelet concentrates (PCs) in 2011, n (\%) } \\
\hline Issues of APC & $150,365(51.4)$ & 347,582 (39.4) (manufactured) & \\
\hline Issues of PPC & $142,281(48.6)$ & 226,202 (60.6) (manufactured) & \\
\hline Issues per 1,000 population & 4.5 & 6.4 & 4.8 \\
\hline Population in 2011 [43], $\mathrm{n}$ & $65.0 \times 10^{6}$ & $81.8 \times 10^{6}$ & $62.5 \times 10^{6}$ \\
\hline \multicolumn{4}{|l|}{ Acute transfusion reactions (ATRs) } \\
\hline Grade 1 & 560 & 0 & - \\
\hline Grade 2 & 54 & 18 & - \\
\hline Grade 3 & 6 & 13 & - \\
\hline Grade 4 & - & 1 & - \\
\hline \multicolumn{4}{|l|}{ Reported ATRs per 100,000 PCs } \\
\hline Total & 211.6 & 3.0 & 48.2 \\
\hline Grade 1 & 191.1 & - & - \\
\hline Grade 2 & 18.4 & - & - \\
\hline \multicolumn{4}{|l|}{ FNHTR } \\
\hline Total & 238 & 3 & $41^{\mathrm{a}}$ \\
\hline Per 100,000 PCs & 81.2 & & \\
\hline \multicolumn{4}{|l|}{ TRALI } \\
\hline Total & 7 & 0 & 0 \\
\hline Grade 3-4 & 1 & & \\
\hline Per 100,000 PCs & 2.4 & & \\
\hline \multicolumn{4}{|l|}{ TTBI } \\
\hline Total & 3 & 2 & 0 \\
\hline Grade 3-4 & 2 & & \\
\hline Per 100,000 PCs & 1.0 & & \\
\hline TTVI (HBV, HCV, HIV) & - & $1(\mathrm{HBV})$ & 0 \\
\hline Haemolytic transfusion reaction & 0 & 2 & 1 \\
\hline \multicolumn{4}{|l|}{ Deaths by PC transfusion-related complications, $\mathrm{n}$} \\
\hline TTBI & 1 & 0 & 0 \\
\hline TRALI & 0 & 0 & 0 \\
\hline ATR & 0 & 0 & 0 \\
\hline
\end{tabular}

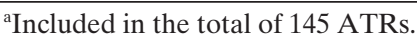

APC $=$ Apheresis platelet concentrates; $\mathrm{PPC}=$ pooled platelet concentrates; FNHTR = febrile non-haemolytic transfusion reactions;

TRALI = transfusion-related acute lung injury; TTBI = transfusion-transmitted bacterial infection; TTVI = transfusion-related viral infection 
Table 2. Benefits and drawbacks of pathogen inactivation/reduction technologies (PRTs) regarding platelets [7, 10, 11, 22, 23, 25, 27, 38, 44]

\begin{tabular}{|c|c|}
\hline Benefits & Drawbacks \\
\hline Elimination of 'window period' infections & $\begin{array}{l}\text { Reduction of in vivo recovery and survival of platelets in normal subjects } \\
\text { by } 14-25 \% \text { and by } 20-27 \% \text {, respectively }\end{array}$ \\
\hline $\begin{array}{l}\text { No development of new tests necessary in case of re-emerging/ } \\
\text { emerging viruses }\end{array}$ & $\begin{array}{l}\text { Decreases in } 1 \mathrm{~h} \text { and } 24 \mathrm{~h} \text { corrected count increment by approximately } \\
12-20 \%\end{array}$ \\
\hline $\begin{array}{l}\text { Extensive elimination of bacterial infections and sepsis associated } \\
\text { to transfusion of platelet concentrates }\end{array}$ & $\begin{array}{l}\text { Possible requirement of a proportionately larger number of platelet } \\
\text { transfusions }\end{array}$ \\
\hline Omission of optional bacterial testing & Possible decreased number of days to the next transfusion \\
\hline Omission of gamma irradiation & Prolongation of the platelet production process \\
\hline Replacement of CMV screening & Possible toxic effects of residual chemical compounds \\
\hline $\begin{array}{l}\text { Possibility to use less stringent donor deferral criteria without } \\
\text { reduction of safety }\end{array}$ & Increase in platelet storage lesions \\
\hline $\begin{array}{l}\text { Paramount option during interruption of testing for transmissible } \\
\text { diseases in case of a pandemic or another public health emergency }\end{array}$ & Cost increase \\
\hline \multicolumn{2}{|l|}{$\begin{array}{l}\text { Prolongation of storage time from } 4 \text { to } 5 \text { days (valid for Germany, } \\
\text { confirmed by the PEI) }\end{array}$} \\
\hline \multicolumn{2}{|l|}{ Reduced rate of ATRs } \\
\hline $\begin{array}{l}\text { Reduction of alloimmunization to leucocyte-borne antigens and } \\
\text { probable prevention of TA-GVHD }\end{array}$ & \\
\hline
\end{tabular}

Babesia spp. (babesiosis) [9-11]. Table 1 gives an overview of the haemovigilance data of 3 European countries derived from the literature. There are considerable variations in reported incidence rates of adverse events between countries (table 1). Platelet concentrates (PCs) carry the highest risk of bacterial contamination compared to all other blood components $[6,9,12,13]$. Transfusion transmitted bacterial infections (TTBIs) caused by PCs were reported with a frequency of 9.57 TTBIs per $10^{6}$ transfused units from 1997 to 2008 in Germany [14]. German haemovigilance data have shown that 6 PCs, which caused fatal infections between 1997 and 2009, had reached the end of their storage life by the time of transfusion. All fatal infections occurred in haematology/oncology patients [14]. To reduce life-threatening septic transfusion reactions caused by bacterial contaminations, the shelf-life of PCs in Germany was restricted to $4 \times 24 \mathrm{~h}$ from midnight of the day of collection [12]. In 2009 and 2010, reported frequencies of TTBIs were reduced to 4.51 and 4.25 TTBIs per $10^{6}$ transfused units, respectively [15].

\section{Platelet Demand and Supply}

From a long-term perspective in Germany, shortages in the supply of platelets are expected due to demographic changes $[16,17]$. Platelet consumption has increased continuously between 2004 and 2011 by $37.3 \%$ in total [18]. A decrease in the number of potential donors $(<65$ years of age) will be accompanied by an increase in elderly patients requiring transfusions [16, 17, 19]. Furthermore, from 2007 to 2050, a rise in cancer incidence by $27 \%$ has been predicted for Germany [16]. The increase in cancer patients will increase the number of PCs needed. Investigations into the demographic changes in 2 different regions of Germany revealed dramatic consequences for future blood supply $[17,20]$. In North-Eastern Mecklenburg Pomerania, the demand for in-hospital blood transfusions will increase by approximately $25 \%$ from 2005 to 2020; simultaneously blood donations will decrease by approximately $27 \%$. This adds up to a predicted deficit of $47 \%$ for in-hospital patients [20]. In Southern Baden-Wuerttemberg, blood product consumption for patients treated in a tertiary care centre and in primary care centres is expected to increase from 2008 to 2030 by more than $10 \%$ and up to $30 \%$, respectively. In parallel, the amount of blood units donated in 2030 is predicted to decrease by $11 \%$ compared to 2007 [17]. These investigations were carried out on red cells only, but it has to be expected that these developments will be even more distinet in platelets [17].

\section{Pathogen Inactivation/Reduction Technologies for PCs}

Currently, pathogen inactivation/reduction technologies (PRTs) for PCs comprise 3 methods: pathogen inactivation (PI) with the Intercept Blood System ${ }^{\mathrm{TM}}$ (IBS) consisting of treatment with amotosalen and ultraviolet (UV) A light (Cerus Corporation, Concord, CA, USA), the Mirasol ${ }^{\circledR}$ technology utilizing riboflavin and irradiation with UVB and UVC light (Terumo BCT, Lakewood, CO, USA), and the Theraflex UV ${ }^{\mathrm{TM}}$ procedure using irradiation with UVC light alone (MacoPharma, Mouvaux, France) [7, 11]. For the Mirasol method, platelets are suspended in plasma or a combination of plasma and additive solution (SSP+, MacoPharma), and treated by the addition of riboflavin (vita$\min \mathrm{B}_{2}$ ) and subsequent exposure to UVB and UVC light of 265-370 $\mathrm{nm}$ delivering a dose of 6.2 Joules $/ \mathrm{cm}^{2}$ for $10 \mathrm{~min}$ ap- 
proximately. Illumination leads to photo-oxidative damage of nucleic acids by generation of oxygen radicals [7, 11]. Similar to other PRTs, negative effects on platelet function have been described for both UVB and UVC light used in the Mirasol and Theraflex UV technology [21]. With IBS, platelets are suspended in approximately $65 \%$ additive solution (InterSol ${ }^{\mathrm{TM}}$, Fenwal Inc., Lake Zurich, IL, USA, or SSP+) and 35\% plasma before amotosalen, a synthetic psoralen compound, is added. Thereafter, 3 Joules/ $\mathrm{cm}^{2}$ UVA light (320-400 nm) are delivered for approximately $5 \mathrm{~min}$ resulting in irreversible cross-linking of nucleic acids and inhibition of replication and transcription of any DNA or RNA. Un-reacted amotosalen and photoproducts are removed by adsorption to a compound adsorption device (CAD) for at least $4 \mathrm{~h}$ and up to $16 \mathrm{~h}$. With IBS-treated platelets, the remaining risk of TTBI is almost negligible, the frequency of ATRs can be reduced, and concomitantly the shelf-life of PCs can be prolonged from 4 to 5 days resulting in wastage rate reduction [22]. While the IBS method has been shown to inactivate the broadest range of viruses, bacteria, and protozoa of all the described technologies to levels below those likely to transmit infection, none of the methods can inactivate prions due to their lack of nucleic acids [11, 23, 24]. Table 2 gives an overview of the benefits and drawbacks of PRTs.

\section{Clinical and Economic Aspects of PI: Model Calculations}

The major part of PCs transfused at the University Hospital of Munich comes from its own production of apheresis platelets at the Department of Transfusion Medicine. Over $60 \%$ of released PCs are used by the Department of Haematology/ Oncology. Therefore, possible clinical and economic aspects of PI were analysed from the perspective of a haematology/ oncology department to estimate benefits and costs on the basis of model calculations. Since in-house production of platelets is not a common approach for German hospitals, 2 scenarios were calculated considering organisational and structural differences. One scenario takes into consideration possible savings by elimination of tests and gamma irradiation and plasma saved when using the IBS procedure, the other scenario does not.

\section{Methods}

Model calculations can be used when study data on a method are limited or missing, to give an estimate on benefits and costs to be expected, and to encourage further research. The model calculations were based on IBS treatment of PCs because this method is to date the most thoroughly studied and most widely used in various countries. In Germany, it is the only PRT technology for PCs approved by the Paul-Ehrlich-Institute (PEI) [22].

\section{Model Input: Clinical Outcome and Associated Costs}

Experience has shown that clinical benefits after introduction of IBS are the reduction of allergic-type ATRs and the prevention of ATRs caused by bacteria in PCs $[10,25]$. So far no German studies are available on ATR rates subsequent to transfusion of IBS-treated platelets. This data was derived from a French study comprising mainly haematology/oncology patients. Without IBS $5.3 \%$ and with IBS $1.4 \%$ ATRs were reported [25]. To determine treatment costs of the clinical symptoms of ATRs, these possible reactions were allocated to grade 1-3 reactions according to the WHO (grade 1: absence of immediate or long-term vital threat; grade 2: long-term morbidity; grade 3: immediate vital threat; grade 4: death of the patient) [25, 26]. In addition, for reactions of grade 2 and 3 a differentiation was made between allergic and bacterial cause to capture the reduction of allergic reactions and the complete avoidance of bacterial reactions by PI technology. To consider the impact of IBS on the frequency of ATRs of different degrees in haematology/oncology patients, data from 2 published studies were used [25, 27]. Treatment patterns and the respective costs for grade 1 ATRs, grade 2/3 ATRs of allergic type, and grade 2 ATRs of bacterial type were calculated assuming work load and drug costs based on the clinical expertise of 2 experts from the Department of Haematology/Oncology. Costing was based on costs and prices of the University Hospital of Munich. Costs for sepsis, that is grade 3 bacterial ATR, were derived from the literature [28]. Costs of grade 1 ATRs were determined on the basis of symptomatic treatment for urti-

Table 3. Cost of acute transfusion reactions (ATRs) of allergic and bacterial origin (for grade 1 ATRs frequency of symptoms related to platelet transfusions from the publication of Osselaer et al. [27] were used)

\begin{tabular}{|c|c|c|c|c|c|}
\hline \multirow[t]{2}{*}{ Grade of ATR } & \multicolumn{2}{|l|}{ Major symptoms } & \multirow{2}{*}{$\begin{array}{l}\text { Treatment } \\
\text { costs }\end{array}$} & \multicolumn{2}{|c|}{ Average costs } \\
\hline & $\begin{array}{l}\text { related symptoms } \\
\text { (due to similar treatment costs) }\end{array}$ & $\begin{array}{l}\text { frequencies of } \\
\text { symptoms [27], \% }\end{array}$ & & average & $\begin{array}{l}\text { weighted costs by frequency } \\
\text { of symptom }\end{array}$ \\
\hline Grade 1 & & & & $€ \quad 104$ & \\
\hline $\begin{array}{l}\text { Symptom groups } \\
\text { Chills }\end{array}$ & & & & & \\
\hline $\begin{array}{l}\text { Chills } \\
\text { Fever }\end{array}$ & $\begin{array}{l}\text { chills, hypotension, flushing } \\
\text { fever. dyspnoea. nausea/vomiting }\end{array}$ & $\begin{array}{l}44 \\
28\end{array}$ & $\begin{array}{r}30.00 \\
252.24\end{array}$ & & $\begin{array}{l}€ 13.2 \\
€ 70.6\end{array}$ \\
\hline $\begin{array}{l}\text { Fever } \\
\text { Urticaria }\end{array}$ & urticaria, rash, itching & $\begin{array}{l}28 \\
28\end{array}$ & $\begin{array}{r}252.24 \\
70.60\end{array}$ & & $€ 19.8$ \\
\hline Grade 2 & & & & $238^{\mathrm{a}}$ & \\
\hline allergic & $\begin{array}{l}\text { urticaria with itching, hypotension, } \\
\text { dyspnoea, bronchospasm }\end{array}$ & & 162.47 & & \\
\hline bacterial & fever $>40^{\circ} \mathrm{C}$, hypotension, dyspnoea & & $€ \quad 314.11$ & & \\
\hline Grade 3 allergic & anaphylaxis and/or shock & & $€ 1,200.00$ & $€ 1,200$ & \\
\hline Grade 3 bacterial & sepsis & & $€ 21,984.00^{\mathrm{b}}$ & $€ 21,984^{\mathrm{b}}$ & \\
\hline
\end{tabular}

${ }^{\mathrm{a}}$ Mean value of allergic and bacterial reaction.

${ }^{\mathrm{b}}$ Costs of ATRs of allergic and bacterial origin were calculated using treatment costs from the University of Munich except costs of bacterial sepsis, which were taken from the literature [28]. 
Table 4. Cost of acute transfusion reactions (ATRs) per $10^{5}$ platelet transfusions without and with the Intercept Blood System ${ }^{\mathrm{TM}}$ (IBS) (total numbers of ATRs after platelet transfusions with platelet concentrates without or with IBS as well as frequencies of grade $1 / 2$ ATRs were derived from the French study of Cazenave et al. [25]; frequencies of grade 3 ATRs are German haemovigilance data published by Funk et al. [45]; numbers were extrapolated to ATRs per $10^{5}$ platelet transfusions; adding up the numbers of ATRs of grade 1-3 results in less than the total number of ATRs in $10^{5}$ platelet transfusions with the difference accounting for transfusion reactions not influenced by pathogen inactivation, such as volume overload)

\begin{tabular}{|c|c|c|c|c|}
\hline & Without & & With IBS & \\
\hline \multirow[t]{2}{*}{ Total ATRs in $10^{5}$ platelet transfusions [25], $\mathrm{n}$} & 530 & & 140 & \\
\hline & ATRs, $n$ & cost of ATRs & ATRs, $n$ & cost of ATRs \\
\hline \multicolumn{5}{|l|}{ Degree and frequency of ATRs in $10^{5}$ platelet transfusions } \\
\hline $61 \%$ grade 1 ATRs $[25]$ & 323 & $€ 33,592$ & 85 & $€ 8,840$ \\
\hline $33 \%$ grade 2 ATRs [25] & 175 & $€ 41,650$ & 46 & $€ 10,948$ \\
\hline 1 allergic grade 3 ATR [45] & 1 & $€ 1,200$ & 1 & $€ 1,200$ \\
\hline 1 septic grade 3 ATR $[45]$ & 1 & $€ 21,984$ & - & - \\
\hline Total costs of ATRs of allergic and bacterial origin in $10^{5}$ platelet transfusions & & $€ 98,426$ & & $€ 20,988$ \\
\hline
\end{tabular}

caria with itching, chills, and fever lasting $<24 \mathrm{~h}$. To obtain the average cost of a single grade 1 ATR, the frequency of symptoms was taken from the study of Osselaer et al. [27], in which the authors report on the frequency of symptoms related to platelet transfusion reactions [27].

\section{Model Input: Platelet Costs}

The cost of a single apheresis PC produced at the University Hospital of Munich is $€ 284$. Costs for IBS material and use of equipment for 2 PCs amount to $€ 152$ (including value added tax (VAT); official list price) (Cerus Europe B.V., MH Amersfoort, The Netherlands). Costs that can be omitted by using IBS during in-house production of PCs are the costs of gamma irradiation and tests for cytomegalovirus (CMV) and syphilis of donors. Acquisition costs for gamma irradiation of 1 conventional PC are $€ 25$, costs for CMV and syphilis testing are $€ 2.19$ and $€ 4.07$, respectively (acquisition costs, staff costs). During the IBS procedure, $400 \mathrm{ml}$ of plasma can be saved per 2 apheresis PCs corresponding to an average value of $€ 32$

\section{Results}

Costs of ATRs of allergic and bacterial origin are summarized in table 3. Model calculations allow to determine estimated savings by reduction of ATRs using IBS-treated platelets. Using the frequency and costs of ATRs per $10^{5}$ PCs transfused results in estimated savings of $€ 77,000$ per $10^{5}$ platelet transfusions (table 4). Approximately 400 PC-related reactions per $10^{5}$ transfusions can be avoided, resulting in benefits for the patients and a saving in staff working time.

Transfusions of PCs causing ATRs usually have to be stopped and the PC discarded. The only exception is mild ATRs grade 1 with symptoms of chills, hypotension, or flushing, where the transfusion often can be continued. Therefore, without IBS treatment, the transfusion of 263 PCs with a value of approximately $€ 74,625$ has to be interrupted and will not be clinically effective.

Calculating with the model input data costs of PCs, laboratory costs, and savings by reduction of ATRs results in an additional cost of $€ 30.2$ per IBS-treated apheresis PC produced at the University Hospital of Munich. This means an estimated cost increase of approximately $11 \%$ per IBS-treated PC compared to a gamma-irradiated PC. A most conservative estimation of the expected cost increase results in up to
$€ 50.85$ per IBS-treated PC if savings by omission of CMV and syphilis testing, reduction of ATRs, and the plasma saved during the procedure are not considered in the calculation. In this conservative estimation, the cost increase would reach up to $18 \%$ per IBS-treated PC compared to a gamma-irradiated PC.

\section{Discussion}

The calculated cost increase of approximately $€ 30-50$ per PItreated PC is associated with patient-related clinical benefits. A cost increase of $€ 50$ per PC lies in between the estimated additional costs from cost effectiveness analyses for PI in various countries [29-31]. These models refer to known risks of bacterial and viral infections and the respective disease consequences or to potential infectious risks of re-/emerging pathogens transmissible by PCs, which would all be avoided by PI. In the context of costs for other accepted blood safety interventions in the developed world, PI for PCs appears to be cost-effective to most authors [29-31].

The perspective of PC transfusion for haematology/oncology patients was chosen because this patient group receives the majority of PCs produced at the University Hospital of Munich. Reported frequencies of ATRs from haemovigilance data of various countries are quite different, but the few clinical studies available suggest considerably higher rates of ATRs [25, 32]. Critically ill haematology/oncology patients are especially susceptible to severe infections due to bacterial contamination [14]. The demand of PCs for this patient group will increase in the future, whereas supply will be short [16, 17]. Therefore, optimal use of blood components is of major importance. National and European Union initiatives aim to achieve this goal by introduction of various measures such as benchmarking and patient blood management to avoid inappropriate transfusions and wastage [33]. PI could potentially add to these measures by saving of plasma, prolongation of shelf-life, decrease of donor deferral, and reduction of ATRs. 
Despite the high safety standard achieved in the past for blood products, bacterial contamination of PCs potentially leading to bacterial sepsis remains a relevant residual risk [6, $9,13,15]$. The implementation of routine bacterial detection methods to screen platelets for bacterial contamination can further reduce but not completely eliminate the risk of PCtransmitted bacterial infection [34]. Bacterial detection assays only detect less than $40 \%$ of contaminated products $[35,36]$. Therefore, comprehensive protection from bacterial infections including fatal sepsis transmitted by contaminated PCs remains the major reason for implementation of PI.

The potential of the PI technique with IBS as a tool to ensure safe blood supply in the case of sudden epidemics has already been demonstrated on the occasion of an outbreak of the Chikungunya virus in an overseas French department [10]. Implementation of PI in various countries is in progress [37]. Centres in Sweden, Belgium and Spain using the IBS technology are no longer performing routine gamma irradiation treatment. The safety and efficacy of IBS-treated PCs and omission of gamma irradiation and CMV screening was also demonstrated in a German single-arm study with thrombocytopenic haematology patients [38]. Avoidance of gamma irradiation would improve the quality of PCs and the logistics of platelet inventory.

Limitations of our model calculations are the lack of German data concerning the avoidance of ATRs in a population of haematology/oncology patients by use of IBS-treated PCs compared to untreated, gamma-irradiated PCs, and the estimation of costs of ATRs by a limited number of clinical experts. Further limitations are: lack of German data investigating staff working time when using the IBS procedure; and lack of data concerning changes in wastage rates by prolongation of shelf-life from 4 to 5 days and by prolongation of the production time for PCs when using the IBS procedure. Due to the lack of reliable data, 2 model assumptions had to be made. Labour costs for the production of PCs could not be considered since no German data on staff working time for procedures like testing of blood products and conducting the IBS procedure have been published. Wastage rates were not considered because they seem to be influenced by various parameters like ineffective platelet inventory management, imbalances in the production supply chain, and outdating [39].
According to PEI data from 2011, wastage of PCs at the producer level was $9.36 \%, 5.25 \%$ for apheresis PCs, and $15.67 \%$ for pooled PCs. Wastage rates at the consumer level were on average $5.63 \%$ in those facilities that reported wastage [18]. No published German data are available evaluating the influence of IBS treatment of PCs and of the extension of the PC shelf-life from 4 to 5 days on wastage rates. However, assuming a mean wastage rate of $12 \%$ in German centres producing apheresis platelets (Junicon ${ }^{\circledR}, 2009$, personal communication) the average wastage rate would drop by approximately $2-5 \%$ because of the prolongation of shelf-life by 1 day accompanied by savings accordingly. This estimation is, however, based on Belgian data [29].

In conclusion, PI seems to be an important option for haematology/oncology patients to almost eliminate PC-related septic transfusion reactions, to reduce PC-related allergic transfusion reactions according to literature-derived clinical data, and to prevent the distribution of re-/emerging pathogens in the future. The total costs of implementing pathogeninactivated PCs in Germany would amount to approximately $€ 26$ million ignoring any possible savings and potential benefits. This number can only be interpreted in comparison to other treatment expenditures. For example, in 2011 costs for 3 tumour necrosis factor (TNF)-alpha inhibitors (adalimumab, etanacerpt, infliximab) amounted to a total of $€ 1.04$ billion [40]. Complete transparency can only be provided once study data on clinical benefits and resource consumption are available in defined patient populations. The societal perspective has to be included in the evaluation of the impact of PI with respect to future developments in blood supply and possible globalization of infectious diseases.

\section{Acknowledgement}

This study was sponsored by Cerus Europe B.V., MH Amersfoort, The Netherlands.

\section{Disclosure Statement}

Helmut Ostermann received a research grant from Cerus Europe B.V.; all other authors declared no conflicts of interest.

\section{References}

1 Apelseth TO, Hervig T, Bruserud O: Current practice and future directions for optimization of platelet transfusions in patients with severe therapyinduced cytopenia. Blood Rev 2011;25:113-122.

2 Stroncek DF, Rebulla P: Platelet transfusions. Lancet 2007:370:427-438.

3 Slichter SJ, Kaufman RM, Assmann SF, McCullough J, Triulzi DJ, Strauss RG, Gernsheimer TB, Ness PM, Brecher ME, Josephson CD, Konkle BA, Woodson RD,
Ortel TL, Hillyer CD, Skerrett DL, McCrae KR, Sloan SR, Uhl L, George JN, Aquino VM, Manno CS, McFarland JG, Hess JR, Leissinger C, Granger S: Dose of prophylactic platelet transfusions and prevention of hemorrhage. N Engl J Med 2010;362:600-613

4 Slichter SJ, Davis K, Enright H, Braine H, Gernsheimer T, Kao KJ, Kickler T, Lee E, McFarland J, McCullough J, Rodey G, Schiffer CA, Woodson R: Factors affecting posttransfusion platelet increments, platelet refractoriness, and platelet transfusion intervals in thrombocytopenic patients. Blood 2005;105:4106-4114.

5 Harker LA, Roskos LK, Marzec UM, Carter RA, Cherry JK, Sundell B, Cheung EN, Terry D, Sheridan W: Effects of megakaryocyte growth and development factor on platelet production, platelet life span, and platelet function in healthy human volunteers. Blood 2000;95:2514-2522.

6 Spiess BD: Platelet transfusions: the science behind safety, risks and appropriate applications. Best Pract Res Clin Anaesthesiol 2010;24:65-83. 
7 Seghatchian J, Hervig T, Putter JS: Effect of pathogen inactivation on the storage lesion in red cells and platelet concentrates. Transfus Apher Sci 2011; 45:75-84.

$>8$ Kiefel V: Reactions induced by platelet transfusions. Transfus Med Hemother 2008;35:354-358.

9 Klein HG: How safe is blood, really? Biologicals 2010;38:100-104.

10 Rasonglès P, Angelini-Tibert MF, Simon P, Currie C, Isola H, Kientz D, Slaedts M, Jacquet M, Sundin D, Lin L, Corash L, Cazenave JP: Transfusion of platelet components prepared with photochemical pathogen inactivation treatment during a Chikungunya virus epidemic in Ile de La Reunion. Transfusion 2009;49:1083-1091.

-11 Stramer SL, Hollinger FB, Katz LM, Kleinman S, Metzel PS, Gregory KR, Dodd RY: Emerging infectious disease agents and their potential threat to transfusion safety. Transfusion 2009;49(suppl 2): 1S-29S.

12 Burger R, Offergeld R: Mitteilungen des Arbeitskreises Blut des Bundesministeriums für Gesundheit: Festlegung der Haltbarkeitsfrist von Thrombozytenkonzentraten mit dem Ziel der Reduktion lebensbedrohlicher septischer Transfusionsreaktionen durch bakterielle Kontamination. Bundesgesundheitsbl Gesundheitsforsch Gesundheitsschutz 2008;51:1484.

13 Walther-Wenke G: Incidence of bacterial transmission and transfusion reactions by blood components. Clin Chem Lab Med 2008;46:919-925.

14 Funk MB, Günay S, et al.: Hämovigilanz-Bericht des Paul-Ehrlich-Instituts 2009: Auswertung der Meldungen von schwerwiegenden Transfusionsreaktionen nach § 63c AMG. 2011; www.pei.de/ SharedDocs/Downloads/vigilanz/haemovigilanz/ publikationen/haemovigillanz-bericht-2009.pdf? blob $b$ publicationFile \& $v=2$; accessed 03/09/2012.

15 Funk MB, Günay S, et al.: Hämovigilanzbericht des Paul-Ehrlich-Instituts 2010: Auswertung der Meldungen von schwerwiegenden Transfusionsreaktionen nach $\S 63 \mathrm{c}$ AMG. 2012; www.pei.de/ SharedDocs/Downloads/vigilanz/haemovigilanz/ publikationen/haemovigillanz-bericht-2010.pdf? blob $=$ publicationFile \& $v=2$; accessed 03/09/2012.

-16 Katalinic A, Peters E, Beske F, Pritzkuleit R: Projection of morbidity 2030 and 2050: impact for the national health system and blood supply. Transfus Med Hemother 2010;37:155-159.

-17 Seifried E, Klueter H, Weidmann C, Staudenmaier T, Schrezenmeier H, Henschler R, Greinacher A, Mueller MM: How much blood is needed? Vox Sang 2011;100:10-21.

18 Henseler O: Paul-Ehrlich-Institut (PEI) report on blood supply 2011. www.pei.de/cln_227/nn_154580/sid_F49158C65AEA1AAE073BFAFC8CB7F0CE/EN/information/ blood-supply/reports/report-blood-supply-2010-201121tfg-contenthtml?_nnn-true; accessed 03/09/2012.

19 Ali A, Auvinen MK, Rautonen J: The aging population poses a global challenge for blood services. Transfusion 2010;50:584-588.

20 Greinacher A, Fendrich K, Brzenska R, Kiefel V, Hoffmann W: Implications of demographics on future blood supply: A population-based crosssectional study. Transfusion 2011;51:1-8.
21 Gelderman MP, Chi X, Zhi L, Vostal JG: Ultraviolet $\mathrm{b}$ light-exposed human platelets mediate acute lung injury in a two-event mouse model of transfusion. Transfusion 2011;51:2343-2357.

22 Webert KE, Cserti CM, Hannon J, Lin Y, Pavenski K, Pendergrast JM, Blajchman MA: Proceedings of a consensus conference: pathogen inactivationmaking decisions about new technologies. Transfus Med Rev 2008;22:1-34.

23 McCullough J, Vesole DH, Benjamin RJ, Slichter SJ, Pineda A, Snyder E, Stadtmauer EA, Lopez-Plaza I, Coutre S, Strauss RG, Goodnough LT, Fridey JL, Raife T, Cable R, Murphy S, Howard Ft, Davis K, Lin JS, Metzel P, Corash L, Koutsoukos A, Lin L, Buchholz DH, Conlan MG: Therapeutic efficacy and safety of platelets treated with a photochemical process for pathogen inactivation: the Sprint trial. Blood 2004;104:1534-1541.

24 Irsch J, Lin L: Pathogen inactivation of platelet and plasma blood components for transfusion using the intercept blood system. Transfus Med Hemother 2011;38:19-31.

25 Cazenave JP, Isola H, Waller C, Mendel I, Kientz D, Laforet M, Raidot JP, Kandel G, Wiesel ML, Corash L: Use of additive solutions and pathogen inactivation treatment of platelet components in a regional blood center: Impact on patient outcomes and component utilization during a 3-year period. Transfusion 2011;51:622-629.

26 Andreu G, Morel P, Forestier F, Debeir J, Rebibo D, Janvier G, Herve P: Hemovigilance network in France: organization and analysis of immediate transfusion incident reports from 1994 to 1998. Transfusion 2002;42:1356-1364.

27 Osselaer JC, Messe N, Hervig T, Bueno J, Castro E, Espinosa A, Accorsi P, Junge K, Jacquet M, Flament J, Corash L: A prospective observational cohort safety study of 5106 platelet transfusions with components prepared with photochemical pathogen inactivation treatment. Transfusion 2008;48:1061-1071.

28 Moerer O, Schmid A, Hofmann M, Herklotz A, Reinhart K, Werdan K, Schneider H, Burchardi H: Direct costs of severe sepsis in three German intensive care units based on retrospective electronic patient record analysis of resource use. Intensive Care Med 2002;28:1440-1446.

29 Moeremans K, Warie H, Annemans L: Assessment of the economic value of the intercept blood system in Belgium. Transfus Med 2006;16:17-30.

30 Bell CE, Botteman MF, Gao X, Weissfeld JL, Postma MJ, Pashos CL, Triulzi D, Staginnus U: Cost-effectiveness of transfusion of platelet components prepared with pathogen inactivation treatment in the United States. Clin Ther 2003;25:24642486.

31 Staginnus U, Corash L: Economics of pathogen inactivation technology for platelet concentrates in japan. Int J Hematol 2004;80:317-324.

32 De Wildt-Eggen J, Nauta S, Schrijver JG, van Marwijk Kooy M, Bins M, van Prooijen HC: Reactions and platelet increments after transfusion of platelet concentrates in plasma or an additive solution: a prospective, randomized study. Transfusion 2000;40:398-403.

- 33 Berger K, Klein HG, Seitz R, Schramm W, Spieser JM: The Wildbad Kreuth initiative: European current practices and recommendations for optimal use of blood components. Biologicals 2011;39:189-193.
34 Schmidt M, Sireis W, Seifried E: Implementation of bacterial detection methods into blood donor screening - overview of different technologies. Transfus Med Hemother 2011;38:259-265.

35 Pearce S, Rowe GP, Field SP: Screening of platelets for bacterial contamination at the welsh blood service. Transfus Med 2011;21:25-32.

36 Walther-Wenke G, Wirsing von Konig $\mathrm{CH}$, Daubener W, Heiden M, Hoch J, Hornei B, Volkers P: Monitoring bacterial contamination of blood components in Germany: effect of contamination reduction measures. Vox Sang 2011;100: 359-366.

37 Reesink HW, Panzer S, McQuilten ZK, Wood EM, Marks DC, Wendel S, Trigo F, Biagini S, Olyntho S, Devine DV, Mumford I, Cazenave JP, Rasongles P, Garraud O, Richard P, Schooneman F, Vezon G, Al Radwan R, Brand A, Hervig T, Castro E, Lozano M, Navarro L, Puig L, Almazan C, MacLennan S, Cardigan R, Franklin IM, Prowse C: Pathogen inactivation of platelet concentrates. Vox Sang 2010;99:85-95.

38 Schlenke P, Hagenah W, Irsch J, Sundin D, Corash L, Lin L, Kirchner H, Wagner T: Safety and clinical efficacy of platelet components prepared with pathogen inactivation in routine use for thrombocytopenic patients. Ann Hematol 2011;90: 1457-1465.

39 Veihola M, Aroviita P, Linna M, Sintonen H, Kekomaki R: Variation of platelet production and discard rates in 17 blood centers representing 10 European countries from 2000 to 2002. Transfusion 2006;46:991-995.

40 Böger RH, Schmidt G: Chapter 16. Antirheumatika und Antiphlogistika; in Schwabe U, Paffrath D (eds): Arzneiverordnungs-Report 2012 - aktuelle Daten, Kosten, Trends und Kommentare. Berlin, Heidelberg: Springer 2012; ISBN 978-3-642-29241-5.

41 Agence nationale de sécurité du médicament et des produits de santé (ansm) rapport d'activité hémovigilance 2011 (juillet 2012). ansmsantefr/ Mediatheque/Publications/Bilans-Rapports-dactivite-Bilans-et-rapports-d-activite\#folder_26762.

42 Bolton-Maggs PBH (ed) and Cohen $\mathrm{H}$ on behalf of the Serious Hazards of Transfusion (SHOT) steering group: The 2011 Annual SHOT Report (2012). ISBN 978-0-9558648-4-1. www.shotuk.org/shotreports/shot-annual-report-summary-2011/.

43 Leben in der EU; data from 2010. europaeu/ documentation/statistics-polls/index_dehtm; accessed 09/07/2012.

44 Osselaer JC, Cazenave JP, Lambermont M, Garraud O, Hidajat M, Barbolla L, Tardivel R, Defoin L, Waller C, Mendel I, Raidot JP, Kandel G, De Meuter R, Fabrigli P, Dehenau D, Arroyo JL, Padron F, Gouezec H, Corral M, Jacquet M, Sundin D, Lin L, Corash L: An active haemovigilance programme characterizing the safety profile of 7,437 platelet transfusions prepared with amotosalen photochemical treatment. Vox Sang 2008;94:315-323.

45 Funk MB, Günay S, Lohmann A, Henseler O, Keller-Stanislawski B: [Evaluation of measures aimed to reduce serious adverse transfusion reactions (hemovigilance data from 1997 to 2008)]. Bundesgesundheitsblatt Gesundheitsforschung Gesundheitsschutz 2010;53:347-356. 